\title{
FEATURES OF THE DEVELOPMENT OF MATHEMATICAL ABILITIES OF STUDENTS IN ENGLISH LESSONS
}

\author{
Fazilya Tillyakhodzhaeva
}

Associate Professor, Kokand State Pedagogical Institute, Uzbekistan

\section{ABSTRACT}

The article shows the development of mathematical abilities of students in English lessons, the importance of this issue in the Resolutions of the Government of the Republic of Uzbekistan, shows the main task of the teacher - to stimulate the speech-thinking activity of students, to create situational learning, in other words, to simulate such an educational situation that will provoke students to spontaneous speech. Mathematics provides ample opportunities for the development of perception, mental operations (comparison, abstraction, symbolization), attention, memory, contributes to the development of logical thinking and cognitive abilities of preschoolers.

KEYWORDS: - English, alphabet, reading and grammar, preschool education, terms, specialist, mathematical actions, arithmetic actions.

\section{INTRODUCTION}

In the Republic of Uzbekistan, special attention is paid to the study of foreign languages. In particular, the Decree of the first President I.Karimov "On measures to further improve the system of learning foreign languages", according to which, starting from the $2013 / 2014$ academic year, the study of foreign languages, mainly English, gradually throughout the republic begins with the first grades of secondary schools in the form of game lessons and conversational language lessons, and starting from the second grade - with the assimilation of the alphabet,

1 Resolution of the First President of the Republic of Uzbekistan on 10.12.2012 PP-1875 "On measures to further improve the system of learning foreign languages" reading and grammar; teaching in higher educational institutions of certain special subjects, especially in technical and international specialties, is conducted in foreign languages.

The concept of the development of the preschool education system of the Republic of Uzbekistan until 2030 was developed pursuant to the Decree of the President of the Republic of Uzbekistan dated September 30, 2018 N PP-3955 " On measures to improve the management system of preschool education" ${ }^{2}$ and contains comprehensive measures for the development of the preschool education system until 2030, which also draws attention to this. Currently, the main issue that needs to be resolved to ensure

\footnotetext{
2 Resolution of the President of the Republic of Uzbekistan On measures to improve the management system of preschool education
} 
CURRENT RESEARCH JOURNAL OF PEDAGOGICS 2(11): 226-232,

November 2021 DOI: https://doi.org/10.37547/pedagogics-crjp-02-11-41

ISSN 2767-3278

(C)2021 Master Journals

\section{Crossref do) 8 Google}

Accepted 25 $5^{\text {th }}$ November, 2021 \& Published 30 ${ }^{\text {th }}$ November, 2021

that children are taught a second language is the availability of specialists. That is why the Ministry of Preschool Education is working on training personnel in this direction ${ }^{3}$.

New specialties have been opened in higher pedagogical universities - the study of English in preschool education. In particular, new specialists of the preschool education system capable of teaching, including in English and Russian, are being trained at the branch of Puchon University in Tashkent and will be trained at the branch of the Herzen Russian Pedagogical University. Thus, this issue is relevant.

Russian is also provided in preschool educational organizations in groups with the Uzbek language of instruction, in groups with the Russian language of instruction in the state language, as well as in the presence of teachers in other languages: English, German, Korean, etc., in groups with the Russian language of instruction in the state language, as well as in the presence of teachers in other languages: English, German, Korean, etc.

In the works on the development of abilities in English lessons N.V. Ermolenko "English in PRE: system and only system", Anukhina I. "Entertaining English for children", Astafieva M.D. "Games for children learning English", Batulina E.M., Surkhay L.G., etc. "English for preschoolers" emphasized that English is not only a school subject, but also a language that we often encounter in everyday life: when using a computer, communicating in social networks,

\footnotetext{
3 Устаджалилова, Х. А., and М. С. Зокирова.

"Совершенствование современного непрерывного образования в Республике Узбекистан." Образование как фактор развития интеллектуально-нравственного потенциала личности и современного общества. 2018. https://scholar.google.com/scholar?oi=bibs\&cluster $=6555367$ $96430704089 \&$ btnI $=1 \& \mathrm{hl}=\mathrm{ru}$
}

watching videos, participating in contests and competitions. In addition, in the modern world, people have begun to travel more, and this is a great opportunity to master another culture and at the same time carry their own ${ }^{4}$.

\section{Methods}

The main purpose of teaching a foreign language is the formation of skills of free communication and practical application, so we can safely say that in English lessons the teacher works in all areas of the formation of functional literacy.

The main task of the teacher is to stimulate the speech-thinking activity of students, to create situational learning, in other words, to simulate such an educational situation that will provoke students to spontaneous speech. The main characteristic of such situations is a practical task: to buy a movie ticket, make an order in a cafe / restaurant, decide where to go / go, etc. English and mathematical literacy, at first glance, are far from each other. But this is not the case. In English lessons, from lesson to lesson, we are working on the formation of functional literacy of students.

The formation of mathematical literacy in English lessons begins in the second grade, when students get acquainted with numerals from 1 to 12 . In the 3rd grade, we learn to count to 100 . They know numbers in Russian, but now they need to memorize them and learn how to use

4 Anukhina I. Entertaining English for children. - St. Petersburg, 2004.

Astafyeva M.D. Games for children learning English. - M.: Mosaic - Synthesis, 2006

Baturina E.M., Surkhay L.G. et al. English for preschoolers. Astana, 2012

Устаджалилова, Хуршида Алиевна, Озода Махмудова, and Дилшод Султанов. "Особенности профессиональнопедагогической подготовки выпускников-будущих учителей математики." Молодой ученый 3-1 (2016): 18-19. 
CURRENT RESEARCH JOURNAL OF PEDAGOGICS 2(11): 226-232,

November 2021 DOI: https://doi.org/10.37547/pedagogics-crjp-02-11-41

ISSN 2767-3278

(C)2021 Master Journals

Crossref dof 81 Google

Accepted 25 $5^{\text {th }}$ November, 2021 \& Published 30 ${ }^{\text {th }}$ November, 2021

them in English, as well as ordinal numerals.

arithmetic operations in the form of a table ${ }^{5}$ :

In the 4th grade, students learn to compare different things and learn to tell the time.

We start with the simplest. Typical task: to perform simple calculations in a foreign language, typical for the usual check of mathematical preparation of students.

"You are visiting your grandmother in the village. Tell your English friend how many domestic birds and animals your grandmother has." Look at the pictures and count the birds. We live in a village, so we can ask you to tell us about your pets or pets.

Ex: Two ducks and two cocks are four birds.

In the 3rd grade, students talk about the age of their relatives and friends, describe competitions using ordinal numerals

In the 4th grade, for example, they think about what time they need to leave the house so as not to be late for school, or what time they need to sit down for lessons in order to have time to complete all the tasks. Here, at first, they distribute the approximate time for completing tasks in each subject.

In elementary school, various game techniques are used, such as "Lotto", "Bingo", we use songs, poems with missing numbers, etc. Tasks should be related to life.

The most commonly used mathematical terms refer to arithmetic. Please note that in Russian we have words such as:

1. Addition, subtraction, division, multiplication the name of the action.

2. Add, subtract, divide, multiply is a verb denoting an action.

3. Plus, minus, divide, multiply - the name of the action that we use in speech when we read the expression, it is it that is used most often.

It's the same in English, so let's present

5 Устаджалилова, Хуршида Алиевна, and Эльмира Наримановна Райхонова. "ОСОБЕННОСТИ ИЗУЧЕНИЯ ОПРЕДЕЛЕНИЙ, ПРОИСХОЖДЕНИЯ МАТЕМАТИЧЕСКИХ ТЕРМИНОВ, ПРАВОПИСАНИЕ И ПРОИЗНОШЕНИЕ ИХ НА АНГЛИЙСКОМ ЯЗЫКЕ." Актуальные научные исследования в современном мире 5-6 (2018): 90-93. 
CURRENT RESEARCH JOURNAL OF PEDAGOGICS 2(11): 226-232,

November 2021 DOI: https://doi.org/10.37547/pedagogics-crjp-02-11-41

ISSN 2767-3278

(C)2021 Master Journals

Crossref do: 81 Google

Accepted 25 $5^{\text {th }}$ November, 2021 \& Published 30 ${ }^{\text {th }}$ November, 2021

\begin{tabular}{|c|c|c|}
\hline Arithmetic action & Arithmetic operation & Used in speech \\
\hline Addition - сложение & Add — прибавлять & Plus - плюс \\
\hline $\begin{array}{l}\text { Subtraction } \\
\text { вычитание }\end{array}$ & Subtract - вычитать & Minus - минус \\
\hline $\begin{array}{l}\text { Multiplication } \\
\text { умножение }\end{array}$ & $\begin{array}{l}\text { Multiply by - } \\
\text { умножать на }\end{array}$ & Times - умножить \\
\hline Division - деление & Divide by - делить на & Divided by - разделить \\
\hline Equality - равенство & $\begin{array}{l}\text { Equals to } \backslash \text { is equal to - } \\
\text { равняться чему-то }\end{array}$ & $\begin{array}{l}\text { Equals to } \backslash \text { is equal to } \backslash \text { is } \\
\text { - равно }\end{array}$ \\
\hline
\end{tabular}

Table 1

The arithmetic problem itself (for example, $2+2$ ) is called problem (in scientific terms) or sum (colloquial version), the solution or answer is answer, and the verb "solve" is to solve (the problem).

I will give examples:

- $2+2=4-$ Two plus two equals four.

- $\quad 7-2=5-$ Seven minus two equals five.

- Often, instead of equals or is equal to, they say simply is. $5 \times 3=15-$ Five times three is fifteen.

- $8 \div 4=2-$ Eight divided by four is two.

- Fractions in English

- $\quad$ Simple fractions - common fractions

- If you are as "fine" with mathematics as I am, I will remind you the most basic thing about fractions.

Common fractions consist of a numerator and a denominator. I remind you, the numerator is on top, the denominator is on the bottom If the number consists of an integer and a fraction, for example $1 \frac{1}{2}-$ this is called a mixed fraction or a mixed number.

The numerator is expressed as a quantitative numeral, and the denominator is ordinal. The most commonly used fractions $1 / 2,1 / 3,1 / 4$ in Russian have not only the "smart" names "one second", "one third", one fourth, but also simple ones: half, third, quarter. It's the same in English.

- $\quad 1 / 2-$ a half, one half.

- $1 / 3-$ a third, one third.

- $1 / 4-$ a quarter, one fourth.

- $1 / 5$ - one fifth.

- $1 / 6-$ one sixth.

- $2 / 3$ - two thirds.

- $3 / 4-$ three fourths.

- $1 / 8$ - one eighth.

- $1 / 10-$ a tenth.

- $1 / 100$ - a hundredth.

- $\quad 1 \frac{1}{4}$ - one and a quarter. 
CURRENT RESEARCH JOURNAL OF PEDAGOGICS 2(11): 226-232,

November 2021 DOI: https://doi.org/10.37547/pedagogics-crjp-02-11-41

ISSN 2767-3278

(C)2021 Master Journals

Crossref doi) 81 Google

Accepted 25 th November, 2021 \& Published $30^{\text {th }}$ November, 2021

- $\quad 1 \frac{1}{2}$ - one and a half.

- $13 / 4$ - one and three quarters.

Note that when the numerator is greater than one, -s is added to the ending, since the denominator is used in the plural (as in Russian: two thirds, three fourths).

- A noun that is defined by a fraction is used with the preposition of:3/4 mile - Three fourths of a mile.

- $\quad 1 / 4$ bottle - A quarter of a bottle.

A noun defined by a mixed fraction is used without a preposition, but in the plural: $2 \frac{1}{1 / 2}$ miles - Two and a half miles.

- $\quad 1 \frac{1}{4}$ bottles - One and a quarter bottles.

Decimals - decimal fractions, decimals

In English, in decimals, an integer is separated from a fraction by a dot (point), and not by a comma, as with us.

The zero before the dot is called zero or (British version) nought. Zero after the dot can be called oh (like the letter "o"), zero, nought. Personally, I always say zero for simplicity, because this word is easier to pronounce and hear. If an integer in a fraction is zero, it is often omitted in speech, starting to speak immediately with "point".

An integer is read as an ordinary quantitative numeral, for example 45.1 - forty five point one. But in the fractional part, each digit is read separately, too, as a quantitative: 2.45 - two point four five (not two point forty five).

Examples:

- $\quad 0.1$ - Point one, zero point one.

- $\quad 0.35$ - Point three five, zero point three five.

- $\quad 1.25$ - One point two five.

- $\quad 35.158$ - Thirty five point one five eight.

- $\quad 15.05$ - Fifteen point zero five.
Percentages in English, difficulties with the verb number

Hundredths can be expressed using percentages, then the standard \% icon is used and the word percent, always used in the singular.

$1 \%$ - One percent. $10 \%$ - Ten percent. $17 \%-$ Seventeen percent.

The difficulty may be caused by the number of the verb in expressions with percentages. For example:Twenty percent of the students are/is present. - 20\% students are present.

The remaining twenty percent of the script has/have been rewritten. - The remaining 20\% of the script was rewritten.

In such cases, the verb agrees in number with the noun after of: Twenty percent of the students are present (т. к. students - plural).

- $\quad$ The remaining twenty percent of the script has been rewritten (т. к. script - ед. число).

Exponentiation in English

- To denote the degree, the expressions to the power of five, to the fifth power, raised to the power of five, raised to the fifth power are used. For the 2nd and 3rd degree, the terms "squared" and "cubed" are used.32 - Three squared, three to the second power.

- 33 - Three cubed, three to the third power.

- $104-$ Ten to the fourth power, ten to the power of four.

- 3024 - Thirty to the power of twenty four.

- The square root is called square root:

- $\sqrt{16}=4-$ The square root of sixteen is four.

- $\sqrt{25}=5-$ The square root of twenty five is five. 
CURRENT RESEARCH JOURNAL OF PEDAGOGICS 2(11): 226-232,

November 2021 DOI: https://doi.org/10.37547/pedagogics-crjp-02-11-41

ISSN 2767-3278

(C)2021 Master Journals

Crossref do) 81 Google

Accepted 25th November, 2021 \& Published 30 ${ }^{\text {th }}$ November, 2021

Mathematical expressions with brackets

Parentheses are called parentheses (single parenthesis) or, more simply, round brackets. If the expression is in parentheses and an operation is applied to it, the word quantity is used.

- $\quad(2+3) \times 4=24-$ Two plus three quantity times four equals to twenty four.

- $\quad(3+5) 2=64$ Three plus five quantity squared is sixty four.

\section{Results AND DISCUSSIONS}

Language for a child is primarily a means of development. Foreign language at an early stage is considered as a means of forming a child's intelligence and developing his abilities, as a means of self-awareness and self-expression, as a means of social interaction through which a child masters the social world. And, as a consequence, in the process of teaching preschoolers a foreign language, the boundaries between organized educational and free-play activities of children are blurred. It is difficult to determine where one ends and the other begins. A inclusion in the joint the creativity of educators and parents makes such a distinction almost ephemeral. Cards with English words on the topic "Mathematics". Mathematical terms from this article can be learned using quizlet cards.

\section{Conclusion}

Currently, the problem of the formation of elementary mathematical representations is one of the most important and urgent tasks in the framework of preparing children for school. Mathematics provides ample opportunities for the development of perception, mental operations (comparison, abstraction, symbolization), attention, memory, contributes to the development of logical thinking and cognitive abilities of preschoolers. Thus, after analyzing the tasks of the textbook, textbooks, workbooks, I found out that they have many means of developing functional literacy.

The goal of the teacher is to teach students to acquire knowledge, skills, and apply them in practical situations, evaluating facts, phenomena, events and making decisions and acting on the basis of the knowledge gained.

\section{REFERENCES}

1. President resolution of the Republic of Uzbekistan on measures to radically improve the management of the preschool education system, Tashkent, September 08.05.2019 PR number -4312

2. Resolution of the First President of the Republic of Uzbekistan on 10.12.2012 PP1875 "On measures to further improve the system of learning foreign languages"

3. Anukhina I. Entertaining English for children. - St. Petersburg, 2004.

4. Ustajalilova Khurshida Alievna, Ozoda Makhmudova and Dilshod Sultanov. "Features of professional and pedagogical training of graduates-future teachers of mathematics." Young Scientist 3-1 (2016): 18-19.5. Astafyeva M.D. Games for children learning English. - M.: Mosaic - Synthesis, 2006

5. Baturina E.M., Surkhay L.G. et al. English for preschoolers. - Astana, 2012

6. Устаджалилова, Хуршида Алиевна, and Эльмира Наримановна Райхонова. "ОСОБЕННОСТИ ИЗУЧЕНИЯ ОПРЕДЕЛЕНИЙ, П ПРОИСХОЖДЕНИЯ МАТЕМАТИЧЕСКИХ ТЕРМИНОВ, ПРАВОПИСАНИЕ И ПРОИЗНОШЕНИЕ ИХ НА АНГЛИЙСКОМ ЯЗЫКЕ." Актуальные научные исследования в современном 
CURRENT RESEARCH JOURNAL OF PEDAGOGICS 2(11): 226-232,

November 2021 DOI: https://doi.org/10.37547/pedagogics-crjp-02-11-41

ISSN 2767-3278

(C)2021 Master Journals

Crossref doi) 81 Google

Accepted 25th November, 2021 \& Published 30 ${ }^{\text {th }}$ November, 2021

мире 5-6 (2018): 90-93.

7. Устаджалилова Х. А., Зокирова М. С. Совершенствование современного непрерывного образования в Республике Узбекистан //Образование как фактор развития интеллектуальнонравственного потенциала личности и современного общества. - 2018. - С. 42-46. 